\title{
Integration of antibody-antigen and receptor-ligand reactions to establish a gold strip biosensor for detection of $33 \beta$-lactam antibiotics
}

Yue $\mathrm{Li}^{1,2}$, Liqiang Liu ${ }^{1,2}$, Chuanlai $\mathrm{Xu}^{1,2^{*}}$, Hua Kuang ${ }^{1,2^{*}}$ and Li Sun ${ }^{3}$

\begin{abstract}
A novel lateral flow immunoassay biosensor, combining the receptor-ligand reaction and antigen-antibody reaction was developed for the detection of $\beta$-lactam antibiotics in milk. The receptor protein, the carboxy-terminal domain of $\beta$-lactam sensor-transducer mutant from Bacillus. licheniformis, served as the recognition element. Colloidal gold (CG)-labelled receptor antibody-receptor ternary complex was applied as a signal transducer probe. The presence of $\beta$-lactams was identified through a color change in the test zone, where the reaction between the complex of CG/antireceptor antibody/receptor and $\beta$-lactam antigen on the test line could be inhibited by $\beta$-lactam residues in the sample, thus leading to a reduction in color signal. Based on the indirect labeling of the receptor with an antibody as a linker, the ability to detect $33 \beta$-lactams was below or near the corresponding maximum residue limit. The proposed lateral flow immunoassay biosensor appears to be an excellent field-based screening tool for the qualitative screening of $\beta$-lactams in milk.
\end{abstract}

Keywords: $\beta$-lactams antibiotics, receptor, monoclonal antibody, lateral flow immunoassay, colloidal gold

\section{INTRODUCTION}

Beta-lactam antibiotics, including penicillins, cephalosporins, carbapenems, and monobactams, are the most frequently used antibiotics for both veterinary and clinical control of infections caused by Gram-positive bacteria. Although, $\beta$-lactams have played an important role in underpinning modern medicine, they have brought serious threats to global public health [1]. Overuse and misuse of lactam antibiotics has contributed to the emergence and wide spread occurrence of antibioticresistant bacteria (especially carbapenem-resistant Acinetobacter baumannii) and antibiotic-resistance genes (ARGs) within the environment [2-4]. Disconcertingly, ARGs can be spread by horizontal gene transfer and human activities [2,5] and eventually transfer to human by ingestion of affected animal-derived food [6]. The World Health Day sound the following alarm: "Antimicrobial resistance: no action today, no cure tomorrow" [7]. In addition to causing antibiotic resistance, $\beta$-lactams, especially penicillins, are also the most common cause of drug-induced allergic reactions $[8,9]$.

Efforts to protect public health have recently focused on the discovery of new drug combinations of antibiotics and of antibiotics with non-antibiotic activity-enhancing compounds [10-12]. In addition, establishing strict regulations and developing monitoring methods are also effective protection measures. The European Union (EU) and China have set maximum residue limits (MRLs) for $\beta$-lactam antibiotics in milk (Table 1). Currently, several analytical methods have been developed to help control the presence of $\beta$-lactams in foodstuffs. Conventional instrumental analytical methods, such as ultra-high-performance liquid chromatography (UPLC) with ultraviolet detection [13], UPLC tandem mass spectrometry [14], and capillary chromatography [15], can provide quantitative results but are time consuming and labor intensive and not suitable for the rapid detection of large numbers of samples. As a fast test technology, immunoassays have been widely used in the fields of food and environmental contamination monitoring, because of their simplicity, sensitivity, and cost-effectiveness [16]. Nevertheless, the

\footnotetext{
${ }^{1}$ State Key Laboratory of Food Science and Technology, Jiangnan University, Wuxi 214122, China

${ }^{2}$ International Joint Research Laboratory for Biointerface and Biodetection, School of Food Science and Technology, Jiangnan University, Wuxi 214122, China

${ }^{3}$ Chinese Academy of Inspection and Quarantine, Beijing 100176, China

* Corresponding authors (emails: kuangh@jiangnan.edu.cn (Kuang H); xcl@jiangnan.edu.cn (Xu C))
} 
antibody-based immunoassay is not the ideal rapid detection method for $\beta$-lactams, because it is difficult to produce a broad-spectrum antibody due to the unstable nature of $\beta$-lactam rings and the large differences in drug structure [17]. As an alternative, receptor-based assays have recently attracted great attention.

Penicillin binding proteins (PBPs) are the target of $\beta$ lactam antibiotics. The structure and conformation of the $\beta$-lactam antibiotics are similar to the transpeptide substrate of the PBPs. Thus, the carbonyl of the $\beta$-lactam ring can be nucleophilically attacked by the hydroxyl group of the serine residue at the active site of PBPs. As a result, the transpeptidase activity of PBPs is inhibited, the peptidoglycan cannot be formed, and cellular content are leaked $[18,19]$. PBPs, served as the receptor for $\beta$-lactam antibiotics, can recognize this class of antibiotics. Therefore, the advantage of using a receptor protein in place of antibodies for the detection of $\beta$-lactams, is that a universal assay, specific for the active form of the $\beta$-lactam structure is obtained. Zhang et al. [20] investigated the applicability of PBP3 of S. pneumonia R6 for the detection of $\beta$-lactams in milk using an enzyme linked immunosorbent assay (ELISA). This assay allowed the detection of 11 penicillins and 16 cephalosporins with detection concentrations corresponding to the MRLs set by the EU. We recently reported an application of gold nanoparticle-labeled I188KS19CG24C mutant BlaR-CTD (BlaR-CTD-M) receptor for the construction of an immunochromatographic assay to detect $\beta$-lactams in milk and chicken samples. This assay provided visible results for detecting $21 \beta$-lactams within $15 \mathrm{~min}$, but the limits of detection (LOD) for some analytes were beyond their corresponding MRLs [21].

Recent years, much attention has been paid to nanomaterials which possess unique optical properties and have been extensively used as a tracking marker in the biosensor development [22,23]. In this study, colloidal gold (CG) was used to label anti-receptor monoclonal antibody $(\mathrm{mAb})$, and then a novel receptor antibodybased biosensor for the screening of $\beta$-lactam residues in milk was developed, which integrates the antibody-antigen reaction and receptor-ligand reaction. The method is based on observing the color intensity of the test zone, the production of which is inversely proportional to the $\beta$ lactam concentration in the sample. The presence of $\beta$ lactams can inhibit the complex of CG-labelled antireceptor $\mathrm{mAb} /$ receptor binding to the $\beta$-lactam antigen immobilized on the test zone. Thus, the lower the amount of receptor added, the higher the competition for free $\beta$ lactams in the samples, and the higher the sensitivity of the biosensor assay. Furthermore, the use of anti-receptor antibody can reduce the amount of receptor used. Based on receptor antibodies, this analytical method appears to be promising for the testing of milk samples for qualitative screening purposes and complies with the limits set by the EU.

\section{EXPERIMENTAL SECTION}

\section{Reagents and equipments}

Mutant $\beta$-lactam receptor protein (BlaR-CTD-M, I188KS19CG24C) from Bacillus. licheniformis ATCC14580 was obtained by our previous study [21]. Beta-lactam antibiotics (purity $\geq 95 \%$ by HPLC) were purchased from J\&K Scientific Co., Ltd. (Beijing, China), Aladdin Co., Ltd. (Shanghai, China), and Yuanye BioTechnology Co., Ltd. (Shanghai, China), respectively. Beta-lactam antibiotics were dissolved in anhydrous $\mathrm{N}, \mathrm{N}$ dimethylformamide (DMF) or ultrapure water at $1 \mathrm{mg} \mathrm{mL}^{-1}$ as stock solutions and stored at $-20^{\circ} \mathrm{C}$ for a maximum of one month. Horseradish peroxidase (HRP) was obtained from Sigma-Aldrich (USA). Goat antimouse immunoglobulin (IgG) was acquired from Abmart Medical Tech Co., Ltd. (Shanghai, China).

The lateral flow immunoassay biosensor was constructed using Unistart CN140 nitrocellulose (NC) membranes (Whatman-Xinhua Filter Paper Co., Ltd., China), polyvinylchloride (PVC) backing card, sample pad (glass-fiber membrane, GL-b01), and absorbent pad (SX18) (JieYi Biotech Co., Ltd., Shanghai, China). The reagents were dispensed using a Biojet Quanti $3000^{\mathrm{TM}}$ Dispenser (XinqidianGene Technology Co., Ltd., Beijing, China). The sensor strips were cut using a CM4000 Guillotine Cutting Module (Kinbio Tech Co., Ltd., Shanghai, China). The color intensity of the test zone was recorded by a hand-held strip scan reader (Huaan Magnech Bio-Tech Co., Ltd., Beijing, China).

\section{Generation of anti-receptor antibodies}

Anti-BlaR-CTD-M antibodies were produced according to the conventional mouse immunization and splenocyte fusion procedure, in combination with indirect competitive ELISA (ic-ELISA) screening [24-26]. A detailed description is presented in the Supplementary information. The affinity constant $\left(K_{\mathrm{a}}\right)$ of antibody was evaluated and calculated as Equation (1).

$K_{\mathrm{a}}=\frac{n-1}{2 \times\left(n\left[A b^{\prime}\right]_{t}-[A b]_{t}\right)}$,

where $n$ represents a multiple of the receptor con- 
Table 1 MRLs and cut-off values of thirty-three $\beta$-lactam antibiotics in milk

\begin{tabular}{|c|c|c|c|c|c|}
\hline \multirow[b]{2}{*}{ Number } & \multirow[b]{2}{*}{$\beta$-lactams } & \multicolumn{2}{|c|}{ MRLs $\left(\mu \mathrm{gg}^{-1}\right)$} & \multicolumn{2}{|c|}{ Cut-off value ${ }^{\mathrm{a}}\left(\mu \mathrm{g} \mathrm{kg}^{-1}\right)$} \\
\hline & & $\mathrm{EU}$ & China & $\begin{array}{l}\text { Biosensor based on anti-receptor } \\
\text { antibody }\end{array}$ & $\begin{array}{l}\text { Gold immunochromatographic } \\
\text { assay based on receptor [21] }\end{array}$ \\
\hline 1 & Benzylpenicillin & 4 & 4 & 4 & 5 \\
\hline 2 & Ampicillin & 4 & 4 & 4 & 10 \\
\hline 3 & Amoxicillin & 4 & 10 & 10 & 20 \\
\hline 4 & Oxacillin & 30 & 30 & 20 & 20 \\
\hline 5 & Cloxacillin & 30 & 30 & 5 & 20 \\
\hline 6 & Dicloxacillin & 30 & $-^{\mathrm{b}}$ & 5 & 20 \\
\hline 7 & Nafcillin & 30 & 30 & 20 & 20 \\
\hline 8 & Penicillin $\mathrm{V}$ potassium & - & - & 5 & 5 \\
\hline 9 & Procaine penicillin & - & 4 & 10 & - \\
\hline 10 & Cefalexin & 100 & 100 & $250-500$ & - \\
\hline 11 & Cefapirin & 60 & 20 & $5-10$ & 20 \\
\hline 12 & Cefoperazone & 50 & - & 5 & 20 \\
\hline 13 & Cefazolin & 50 & 20 & 50 & - \\
\hline 14 & Ceftiofur & 100 & 100 & 25 & 50 \\
\hline 15 & Cefquinome & 20 & 20 & $5-10$ & 10 \\
\hline 16 & Cefalonium & 20 & - & 5 & - \\
\hline 17 & Cefacetrile & 125 & - & $<50$ & - \\
\hline 18 & Cefamandole & - & - & 5 & 20 \\
\hline 19 & Moxalactam & - & - & 10 & 20 \\
\hline 20 & Cefalotin & - & - & 10 & 20 \\
\hline 21 & Cefotaxime & - & - & $50-100$ & 100 \\
\hline 22 & Cefadroxil & - & - & $>250$ & - \\
\hline 23 & Cefuroxime & - & - & $>100$ & 100 \\
\hline 24 & Cephradine & - & - & 2000 & - \\
\hline 25 & Cefoxitin & - & - & $50-100$ & - \\
\hline 26 & Ceftriaxone & - & - & 10 & 25 \\
\hline 27 & Cefathiamidine & - & - & 10 & - \\
\hline 28 & Cefaclor & - & - & 25 & 25 \\
\hline 29 & Cefixime & - & - & 100 & - \\
\hline 30 & Cefepime & - & - & 10 & - \\
\hline 31 & Cephalothin & - & - & 10 & 10 \\
\hline 32 & Meropenem & - & - & 20 & 20 \\
\hline 33 & Ertapenem & - & - & 20 & - \\
\hline
\end{tabular}

a) Cut-off value is defined as the minimum concentration giving a completely disappeared $\mathrm{T}$ line; $\mathrm{b}$ ) no MRL requirement or no testing.

centration in each group; $\left[A b^{\prime}\right]_{t}$ and $[A b]_{t}$ represent the antibody concentrations $\left(\mathrm{mmol} \mathrm{mL}^{-1}\right)$ corresponding to $50 \% A_{\max }$ in different groups. $A_{\max }$ was defined as the $\mathrm{OD}_{450}$ value of the top of the S-shaped curve.

Mouse immunization experiments were conducted according to institutional ethical guidelines and approved by the Committee on Animal Welfare of Jiangnan University (Wuxi, China) (SYXK (Su) 2016-0045).

\section{Preparation of HRP-labelled antibody}

One milligram of HRP was dissolved in $0.2 \mathrm{~mL}$ ultrapure water, followed by the addition of $0.1 \mathrm{~mL}$ of $0.06 \mathrm{~mol} \mathrm{~L}^{-1}$ 
$\mathrm{NaIO}_{4}$. Thirty minutes after reduction at $4^{\circ} \mathrm{C}, 0.1 \mathrm{~mL}$ of $0.16 \mathrm{~mol} \mathrm{~L}^{-1}$ glycol was added, followed by stirring for $30 \mathrm{~min}$ at room temperature. Next, $1 \mathrm{mg}$ anti-receptor antibody was added dropwise into the above solution with the $\mathrm{pH}$ adjusted to 9.0 with $0.05 \mathrm{~mol} \mathrm{~L}^{-1}$ sodium carbonate buffer ( $\mathrm{pH} 9.6$ ). After stirring overnight at $4^{\circ} \mathrm{C}$, $40 \mu \mathrm{L}$ of $\mathrm{NaBH}_{4}\left(5 \mathrm{mg} \mathrm{mL}^{-1}\right.$ in ultrapure water) was quickly added and left to stand for $2 \mathrm{~h}$ at $4^{\circ} \mathrm{C}$. Then, an equal volume of saturated sodium sulfate was slowly added and kept standing for another $2 \mathrm{~h}$ at $4^{\circ} \mathrm{C}$. After centrifugation at $5000 \times g$, for $10 \mathrm{~min}$ at $4^{\circ} \mathrm{C}$, the precipitate representing the conjugates were dissolved in $0.01 \mathrm{~mol} \mathrm{~L}^{-1}$ phosphate buffered saline (PBS, pH 7.4) and then dialyzed against PBS. By addition of an equal volume of glycerinum, the final conjugates were aliquoted and stored at $-20^{\circ} \mathrm{C}$ in the dark.

Preparation of $\mathrm{CG} / \mathrm{anti}$-receptor $\mathrm{mAb} /$ receptor conjugates CG with an average particle diameter of $35 \mathrm{~nm}$ was prepared using the seed growth method as previously described [21] (detailed steps can be found in the Supplementary information). Then, CG/anti-receptor $\mathrm{mAb} /$ receptor conjugates were prepared through physical adsorption, according to previous references [27,28], with some modifications. Briefly, $1 \mathrm{~mL}$ of CG solution was supplemented with $40 \mu \mathrm{L}$ of $0.01 \mathrm{~mol} \mathrm{~L}^{-1} \mathrm{~K}_{2} \mathrm{CO}_{3}$ solution, followed by the addition of $20 \mu \mathrm{g}$ anti-receptor antibody (diluted in $0.02 \mathrm{~mol} \mathrm{~L}^{-1}$ borate buffer, $\mathrm{pH} 8.4$ ). This was then mixed and left standing for $45 \mathrm{~min}$ at room temperature. After this, the redundant sites on the CG surface were blocked by addition of $10 \%(w / v)$ bovine serum albumin (BSA) at a final concentration of $1 \%$, with stirring for $2 \mathrm{~h}$ at room temperature. Next, $5 \mu \mathrm{g}$ of receptor protein BlaR-CTD-M was added and the mixture was incubated for $30 \mathrm{~min}$ at room temperature. Nonspecifically bound antibody, receptor, BSA, and other chemicals were then removed by centrifugation at 8000 $\times g$ for $45 \mathrm{~min}$ at $4^{\circ} \mathrm{C}$. The precipitate was washed twice with $0.02 \mathrm{~mol} \mathrm{~L}^{-1}$ Tris- $\mathrm{HCl}$ (containing 1\% BSA, $2 \%$ Tween-20, and 5\% trehalose, $\mathrm{pH} 8.2$ ) and re-suspended in $0.02 \mathrm{~mol} \mathrm{~L}^{-1}$ Tris- $\mathrm{HCl}$ (containing 1\% BSA, 2\% Tween$20,5 \%$ trehalose, and $\left.0.05 \% \mathrm{NaN}_{3}, \mathrm{pH} 8.2\right)$ and then stored at $4^{\circ} \mathrm{C}$ until use.

\section{Development of the lateral flow immunoassay biosensor}

The lateral flow immunoassay biosensor was assembled in a similar way to conventional lateral flow immunochromatography assays (LFIA) [29,30]. As shown in Fig. 1, four components, PVC backing card, sample pad, NC membrane, and absorbent pad were used. The $\beta$ lactam antigen (detailed preparation procedures are given in the Supplementary information) and secondary antibody (goat anti-mouse IgG) were dispensed at $0.9 \mu \mathrm{L} \mathrm{cm}^{-1}$ with a $5 \mathrm{~mm}$ interval, to the central part of the NC membrane, to prepare a test line ( $\mathrm{T}$ line) and control line (C line). The reagents on the NC membrane

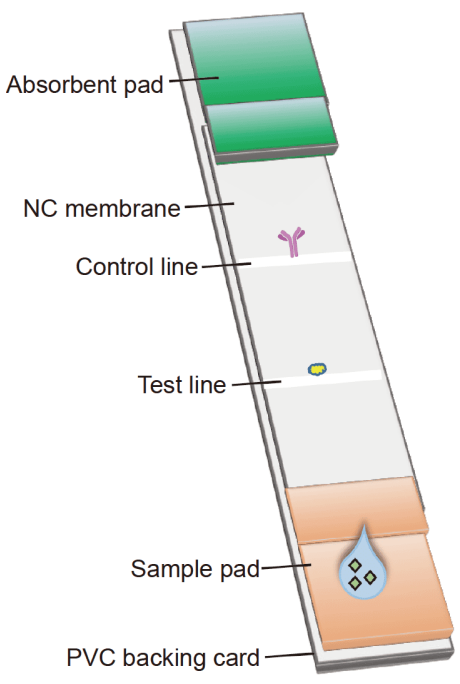

B-lactams Amp-BSA
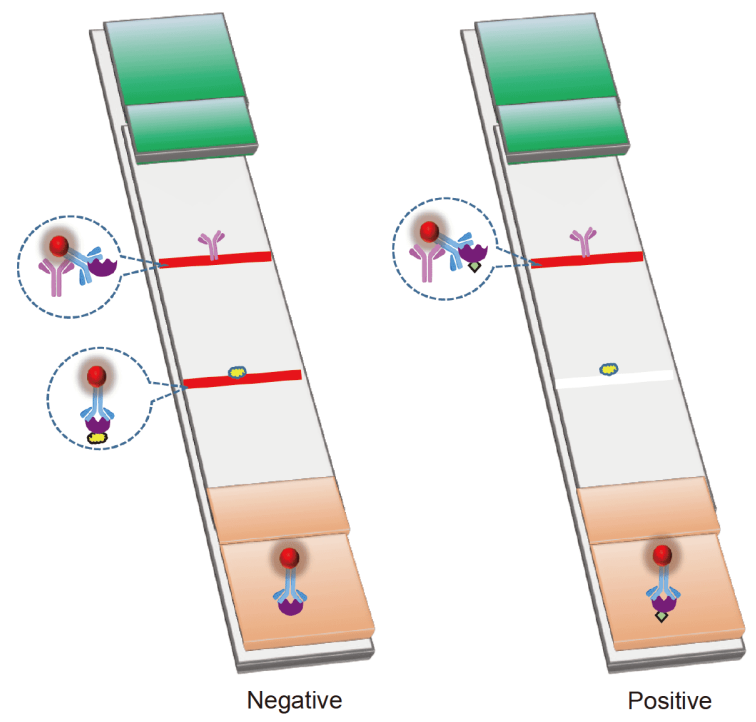

Receptor $\Upsilon^{\prime}$ Goat anti-mouse IgG
CG/anti-receptor mAb/receptor

Figure 1 Assemblage and principle of the receptor antibody-based biosensor assay. 
were immobilized by drying overnight at $37^{\circ} \mathrm{C}$. For construction of the strip, the dried NC membrane was first attached to the central part of the PVC backing card and the sample pad and absorbent pad were separately affixed to the ends of the NC membrane with a 3-mmwide overlap. After assembly, the card was cut into 2.9mm-wide strips using a cutter. The strips were hermetically sealed in bags containing desiccant and stored in a desiccator. The strip assembly procedure was conducted in a $20-24^{\circ} \mathrm{C}$ room, with a relative humidity not exceeding $30 \%$.

\section{Qualitative analysis using biosensor strips}

The protocol for using the biosensor strips to determine $\beta$-lactams was as follows: for efficient diffusion in the strip, $5 \mu \mathrm{L}$ of $\mathrm{CG} /$ anti receptor $\mathrm{mAb} /$ receptor solution, $45 \mu \mathrm{L}$ of running buffer $\left(0.02 \mathrm{~mol} \mathrm{~L}^{-1}\right.$ Tris- $\mathrm{HCl}$ containing $1 \% \mathrm{BSA}, 2 \%$ Tween-20, 5\% trehalose, $0.05 \% \mathrm{NaN}_{3}$, and $5 \%$ surfactant, $\mathrm{pH} 8.2$ ), and $150 \mu \mathrm{L}$ of sample solution (or standard solution) were first mixed in a microwell. Five min after incubation at room temperature, the strips were vertically inserted into the solution and further incubated for $5 \mathrm{~min}$. During this time, the solution migrated by capillary action, passing through the NC membrane toward the absorbent pad. The presence of analytes could be qualitatively confirmed by a color change on the $\mathrm{T}$ line using the naked eye (within 10-15 $\mathrm{min}$ ). The visible LOD (vLOD) was defined as the minimum concentration producing an obviously weaker $\mathrm{T}$ line than the negative sample and the cut-off value was the minimum concentration giving a completely absent $\mathrm{T}$ line.

\section{Sample pretreatment for the biosensor and LC-MS/MS}

The milk sample preparation process for the biosensor strips was similar to our previous report [21]. The milk sample pretreatment method for the liquid chromatograph (LC)-mass spectrometer (MS)/MS was according to the national standards of the People's Republic of China (GB/T 22975-2008 and GB/T 22989-2008) and a detail description is presented in the Supplementary information.

\section{Milk sample analysis}

Negative milk samples were separately spiked with 33 different $\beta$-lactam antibiotics at different concentrations (covering their MRLs) by mixing for $15 \mathrm{~min}$ at $4^{\circ} \mathrm{C}$. The spiked samples were extracted with the above-mentioned protocol and then analyzed using the proposed biosensor strips. Each spiked concentration was tested three times.
To validate the reproducibility and accuracy of the proposed biosensor strips. Three analytes (benzylpenicillin, ampicillin, and cefapirin) spiked into the samples were analyzed using LC-MS/MS. Details of the experiment conditions used in relation to the LC-MS/MS can be found in the Supplementary information.

\section{RESULTS AND DISCUSSION}

\section{Principle of the lateral flow immunoassay biosensor}

The operating principle of the biosensor strip is similar to conventional LFIA strips $[29,31,32]$, except that it involves receptor-ligand reactions between BlaR-CTD-M and $\beta$-lactams, and its principle is illustrated in Fig. 1. During the first $5 \mathrm{~min}$ of incubation process, the receptor-ligand reaction and immunoreaction result in the formation of complexes of CG/anti-receptor $\mathrm{mAb} / \mathrm{re}$ ceptor (negative) or CG/anti-receptor $\mathrm{mAb} /$ receptor/ analyte (positive). During the second 5 min of incubation process, the solution migrates along the NC membrane, at which point the receptor-ligand reaction and immunoreaction occur again. The CG/anti-receptor mAb/ receptor complexes are captured by ligand ( $\beta$-lactam antigen) and immobilized on the test line, producing a red $\mathrm{T}$ line. Excess CG/anti-receptor $\mathrm{mAb} /$ receptor continues to migrate and is captured by the second antibody (goat-anti mouse IgG) immobilized on the control line, causing a red $\mathrm{C}$ line. Therefore, two red lines are observed for a negative sample, whereas only a red $\mathrm{C}$ line is formed for a positive sample. Regardless of the presence or absence of analytes in the sample, a red C line always appears, indicating that the strip is working properly.

Screening of anti-receptor antibody and $\boldsymbol{\beta}$-lactam antigen Based on the principle of our biosensor, it should be noted that the lower the amount of receptor used, the weaker the competition between the immobilized $\beta$-lactam antigen against receptor, and the higher sensitivity of the biosensor assay. The use of high-affinity anti-receptor antibody can reduce the amount of receptor used. Therefore, the affinity of antibody $\left(0.3 \mu \mathrm{g} \mathrm{mL}^{-1}\right)$ to BlaRCTD-M was evaluated using ELISA with BlaR-CTD-M $\left(0.1 \mu \mathrm{g} \mathrm{mL}^{-1}\right)$ coated onto 96-well plates. Fig. 2a shows that $\mathrm{mAb} 6 \mathrm{~B} 11$ exhibited the highest titer for BlaR-CTDM. Then the $K_{\mathrm{a}}$ of $6 \mathrm{~B} 11$ to receptor was determined. Based on Fig. 2b, the $K_{\mathrm{a}}$ was calculated to be $4.5 \times$ $10^{10} \mathrm{~L} \mathrm{~mol}^{-1}$. Thus $6 \mathrm{~B} 11$ was used for the construction of the lateral flow immunoassay biosensor.

Three $\beta$-lactam antigens [ampicillin (Amp)-BSA, cefapirin (Cefa)-BSA, and cefoperazone (CPZ)-BSA] were 

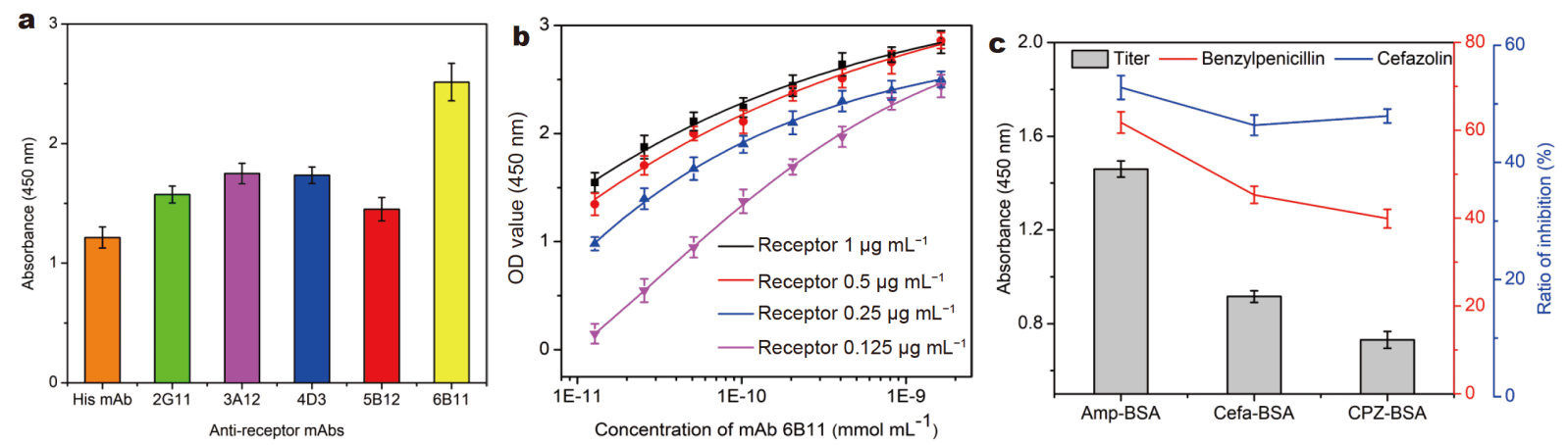

Figure 2 Evaluation of anti-receptor antibodies and $\beta$-lactam antigens. (a) The titer of antibodies to receptor BlaR-CTD-M was evaluated by ELISA. (b) The $K_{\mathrm{a}}$ of mAb 6B11 was evaluated. (c) The affinity and sensitivity of $\beta$-lactam antigens (Amp-BSA, Cefa-BSA, and CPZ-BSA) to receptor BlaRCTD-M was evaluated.

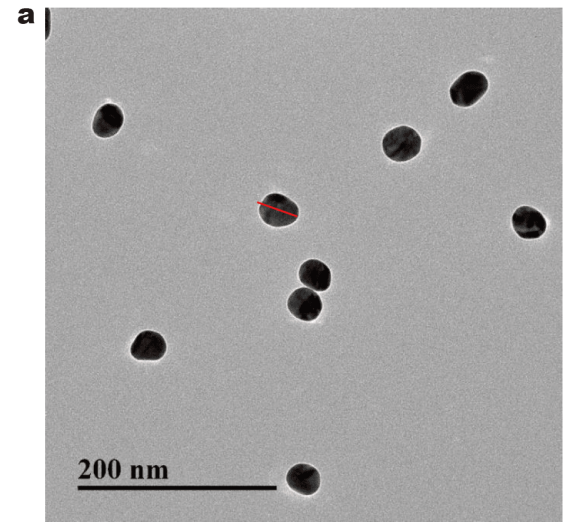

b

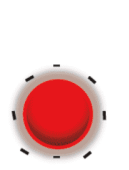

CG

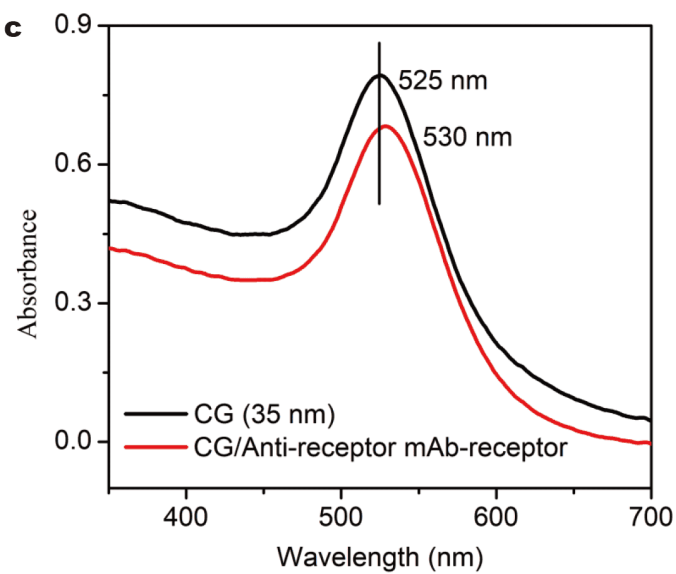

Receptor

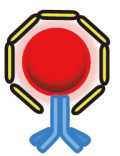

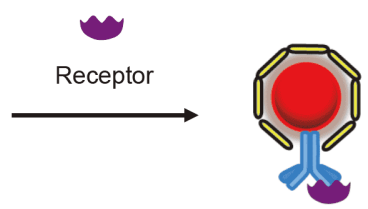

Figure 3 Preparation of CG/anti-receptor mAb/receptor conjugates. (a) TEM image of CG solution. (b) The route for preparation of CG/antireceptor $\mathrm{mAb} /$ receptor. (c) UV-Vis spectra of CG and CG/anti-receptor $\mathrm{mAb} /$ receptor conjugate.

assessed by measuring their ability to compete with $\beta$ lactams for binding to the receptor. Indirect competitive ELISA was implemented with Amp-BSA, Cefa-BSA, and CPZ-BSA $\left(1 \mu \mathrm{g} \mathrm{m}^{-1}\right)$ immobilized on the plates. Then, benzylpenicillin $\left(0\right.$ and $\left.1 \mathrm{ng} \mathrm{mL}^{-1}\right)$ and cefazolin $(0$ and $10 \mathrm{ng} \mathrm{mL}^{-1}$ ) were added to compete with the Amp-BSA, Cefa-BSA, and CPZ-BSA for binding the BlaR-CTD-M $\left(0.3 \mu \mathrm{g} \mathrm{mL}^{-1}\right)$. When HRP-labelled $6 \mathrm{~B} 11$ was added, results could be obtained and are presented in Fig. 2c. In terms of titer, Amp-BSA showed the highest affinity for the receptor. In parallel, Amp-BSA exhibited the weakest ability for competition with benzylpenicillin and cefazolin for binding to the receptor. In summary, Amp-BSA produced high affinity and high sensitivity for the detection of lactams.

\section{Preparation of CG/anti-receptor $\mathrm{mAb} /$ receptor conjugates} CG possesses unique optical properties and has been used extensively as a tracking marker in the establishment of biosensors [22]. The transmission electron microscopy (TEM) image (displayed in Fig. 3a) showed that the CG particles in our preparation had a uniform diameter of approximately $35 \mathrm{~nm}$ and that the CG/anti-receptor $\mathrm{mAb} /$ receptor conjugates were prepared mainly by electrostatic adsorption (Fig. 3b). After conjugation, the characterization process was conducted using ultraviolet- 
visible spectroscopy (UV-Vis). The UV-Vis spectra (Fig. 3c) showed that the CG alone had a characteristic absorption peak at $525 \mathrm{~nm}$, while the peak was slightly red shifted to $530 \mathrm{~nm}$ after antibody coupling, indicating that the CG/anti-receptor $\mathrm{mAb} /$ receptor probe was successfully prepared.

The amounts of receptor and anti-receptor antibody added in the conjugation solution determine the ability of the CG/anti-receptor $\mathrm{mAb} /$ receptor to bind to the targets present in the sample and the antigen fixed on the $\mathrm{T}$ line, and further affect the visibility and sensitivity of the biosensor assay. A too low dosage leads to poor color production, while a too high dosage causes poor sensitivity and high cost. As shown in Fig. S1, we found that the inhibition intensity (when testing 0 and $4 \mathrm{ng} \mathrm{mL}^{-1}$ of benzylpenicillin in milk) was more obvious if $5 \mu \mathrm{g}$ of the receptor and $15 \mu \mathrm{g}$ of the anti-receptor antibody were added for labelling.

Prior to the coupling process, different volumes of $0.01 \mathrm{~mol} \mathrm{~L}^{-1} \mathrm{~K}_{2} \mathrm{CO}_{3}(10,20,40$, and $60 \mu \mathrm{L})$ were added into the CG solution, to adjust the $\mathrm{pH}$. The $\mathrm{pH}$ value of the conjugation system has a great influence on the charge on the CG and antibodies [27,33], and optimal volume of $0.01 \mathrm{~mol} \mathrm{~L}^{-1} \mathrm{~K}_{2} \mathrm{CO}_{3}$ should provide high sensitivity and high visibility. When the probes, obtained under different $\mathrm{pH}$ values, were used to construct the strips to analyze benzylpenicillin ( 0 and $4 \mathrm{ng} \mathrm{mL}^{-1}$ prepared in milk), we found that $40 \mu \mathrm{L}$ of $0.01 \mathrm{~mol} \mathrm{~L}^{-1}$ $\mathrm{K}_{2} \mathrm{CO}_{3}$ provided the most satisfactory color signal and sensitivity (Fig. S2).

\section{Optimization of the biosensor conditions}

The surfactants used in the running buffer impart the NC membrane (hydrophilic) with a certain degree of hydrophilicity, giving samples good fluidity. However, it is worth noting that if the sample solution migrates too fast or too slowly, it can bring about disappointing sensitivity and colorimetry. In this study, six different surfactants (polyvinyl pyrrolidone (PVP), polyethylene glycol (PEG), BSA, Tween-20, Brij 35, and On-870) were evaluated (Fig. S3). When 5\% ( $w / v)$ PVP, PEG, Tween-20, and Brij 35 were respectively added into the suspension buffer, the sample solutions had a poor fluidity and could not reach the absorbent pad within $5 \mathrm{~min}$, resulting in poor visibility. The biosensor strip displayed the highest color intensity and best sensitivity when On-870 was supplemented; therefore, this surfactant was chosen to add to the running buffer for the strip assay.

The concentration of $\beta$-lactam antigen coated onto the $\mathrm{T}$ line also has a great influence on the sensitivity of the biosensor [34]. The higher the affinity of the antigen (ligand) to the receptor, the stronger the competition of the antigen ligand, and the lower the sensitivity of the biosensor. However, if the affinity of the antigen ligand to the receptor is too low, the $\mathrm{T}$ line color intensity of negative samples will be very low, resulting in poor accuracy and reproducibility. Based on the ic-ELISA assessment results, Amp-BSA (0.5 and $\left.1 \mathrm{mg} \mathrm{mL}^{-1}\right)$ and Cefa-BSA (0.5 and $\left.1 \mathrm{mg} \mathrm{mL}^{-1}\right)$ were tested by determining benzylpenicillin ( 0 and $4 \mathrm{ng} \mathrm{mL}^{-1}$ prepared in milk) using the biosensor. Fig. S4 shows that $1 \mathrm{mg} \mathrm{mL}^{-1}$ of Amp-BSA brought about the best visibility (when detecting negative samples) and the highest sensitivity (when detecting positive samples).

\section{Milk sample analysis}

To evaluate the sensitivity of the biosensor strip, milk samples containing different concentrations of $\beta$-lactams were tested under optimal conditions. Colorimetric images of the strips in the presence of different antibiotic concentrations were obtained using a smartphone camera. Figs 4-6 concluded that nine types of penicillins, twenty-two types of cephalosporins, and two types of carbapenems could be detected. In summary, with increasing concentrations of each analyte, the color intensity of the corresponding $\mathrm{T}$ line gradually decreased and even completely disappeared. The cut-off values of benzylpenicillin, ampicillin, oxacillin, cloxacillin, dicloxacillin and nafcillin were $4,4,20,5,5$ and $20 \mu \mathrm{g} \mathrm{kg}^{-1}$, respectively, below or equal to their respective MRLs set by EU or China. The cut-off value of amoxicillin was $10 \mu \mathrm{g} \mathrm{kg}^{-1}$, higher than its MRL set by EU, but equal to its MRL set by China. The cut-off values of cefapirin, cefquinome, cefoperazone, cefazolin, ceftiofur, cefalonium and cefacetrile were $5-10,5-10,5,50,25,5$, and $<50 \mu \mathrm{g} \mathrm{kg}^{-1}$, respectively, below or equal to their respective MRL set by EU. The cut-off value of cephalexin was 250-500 $\mathrm{g} \mathrm{kg}^{-1}$, higher than its MRL set by EU and China. However, much weaker $\mathrm{T}$ line, when compared with the negative sample, was observed at cephalexin concentration of $100 \mu \mathrm{g} \mathrm{kg}^{-1}$. The cut-off values of meropenem and ertapenem were both $20 \mu \mathrm{g} \mathrm{kg}^{-1}$. Carbapenem antibiotics have a broad spectrum, strong antibacterial activity, and high stability to $\beta$-lactamase, so they have become one of the most important antibacterial drugs for the treatment of severe bacterial infections. However, they pose potentially neurotoxic effects and may cause seizures if used in overdose [35], and thus there is an urgent requirement for monitoring carbapenems. 


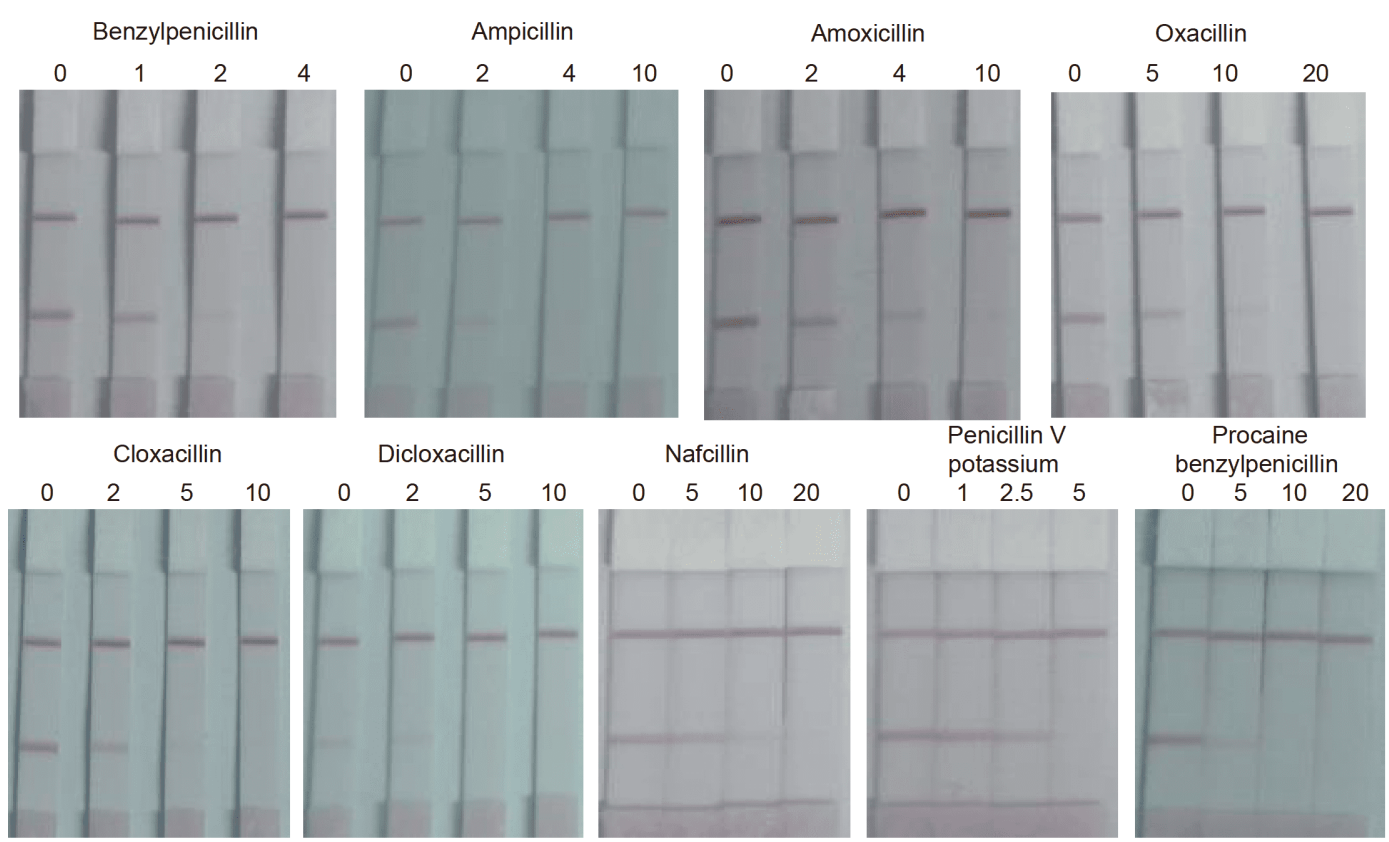

Figure 4 The strip images of testing penicillin antibiotics with different concentrations $\left(\mu \mathrm{gg}^{-1}\right)$ in milk samples by the biosensor.

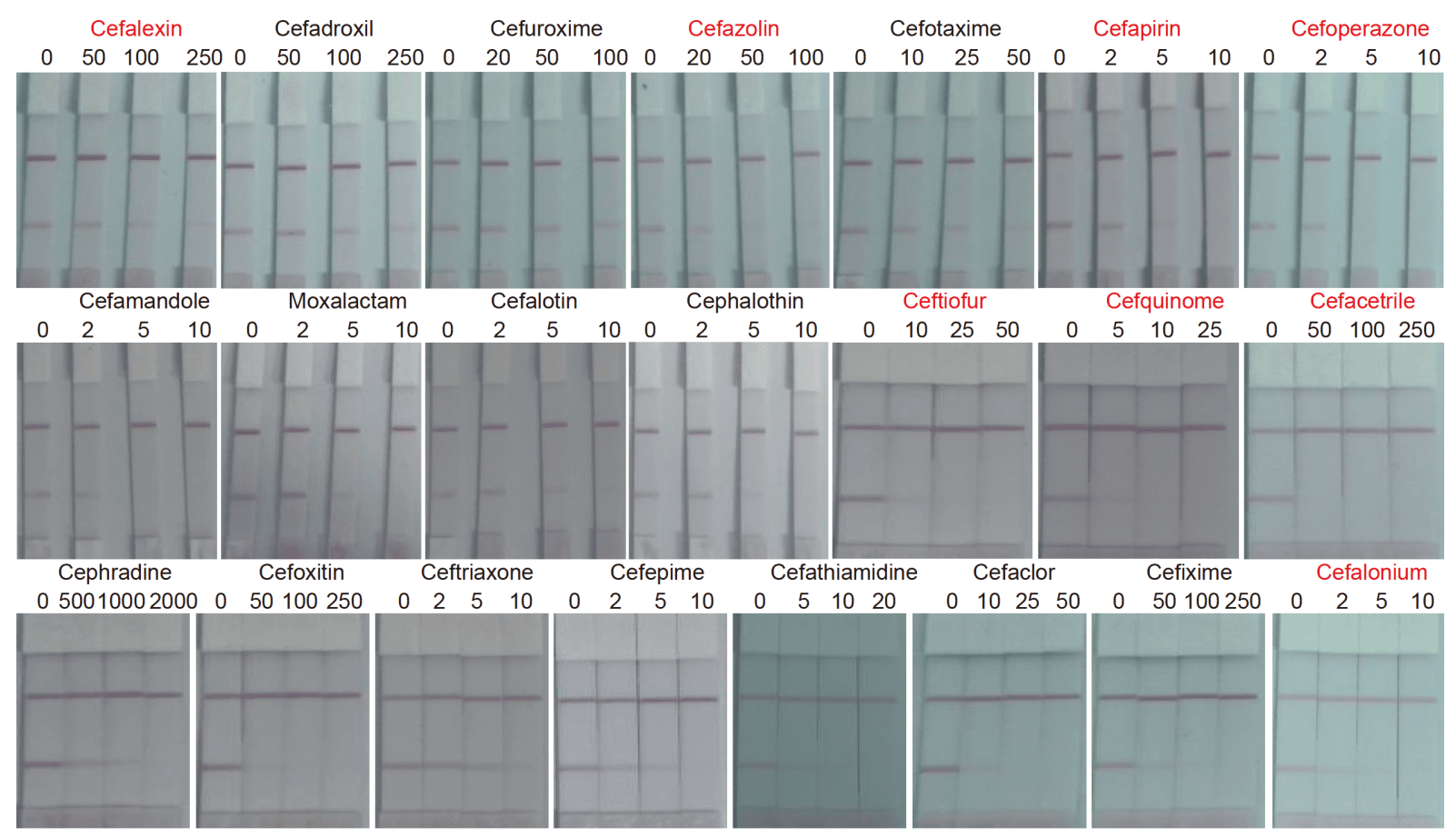

Figure 5 The strip images of testing cephalosporin antibiotics with different concentrations $\left(\mu \mathrm{g} \mathrm{kg}^{-1}\right)$ in milk samples by the biosensor.

The cut-off values of biosensor based on anti-receptor antibody developed in this study and assay based on receptor developed in our previous study were compared and summarized in Table 1. It could be found that the sensitivity of the assay based on indirect labeling receptor by an antibody as a linker was $0-5$ times higher than that of the direct labeling receptor. The cut-off values of benzylpenicillin, ampicillin, amoxicillin and cefalexin in milk based on the direct labeling receptor by CG were higher than their MRLs set by EU and China. However, 


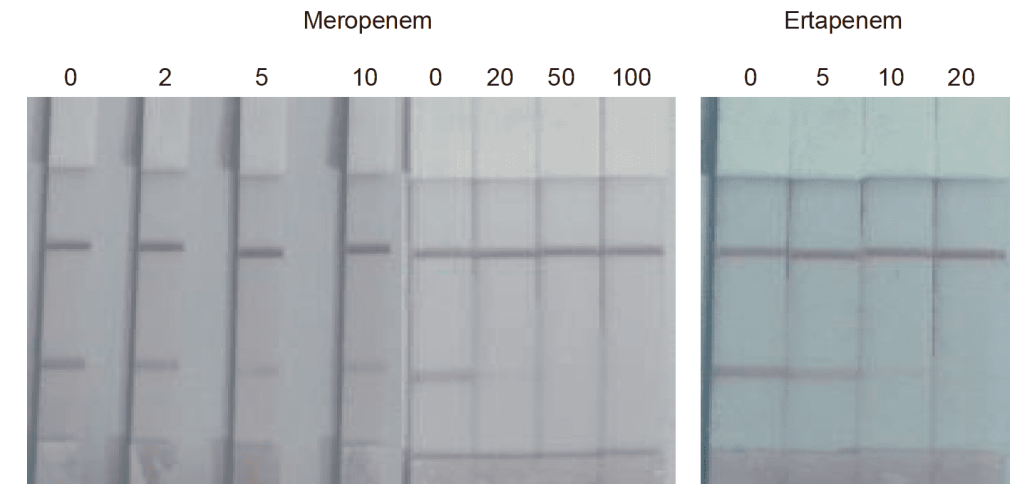

Figure 6 The strip images of testing carbapenem antibiotics with different concentrations $\left(\mu \mathrm{g} \mathrm{kg}^{-1}\right)$ in milk samples by the biosensor.

Table 2 The results of detecting benzylpenicillin, ampicillin, and cefapirin in spiked milk samples by LC-MS/MS and the receptor antibody-based biosensor $(n=3)$

\begin{tabular}{|c|c|c|c|c|c|}
\hline \multirow[b]{2}{*}{ Milk samples } & \multirow{2}{*}{$\beta$-lactams } & \multirow{2}{*}{ Spiked levels $\left(\mu \mathrm{g} \mathrm{kg}^{-1}\right)$} & \multirow{2}{*}{$\begin{array}{l}\text { Biosensor strip } \\
\text { visual results }^{\mathrm{a}}\end{array}$} & \multicolumn{2}{|c|}{ LC-MS/MS } \\
\hline & & & & $\begin{array}{l}\text { Measuring concentration } \\
\left(\mu \mathrm{g} \mathrm{kg}^{-1}\right)\end{array}$ & $\begin{array}{c}\text { Recovery } \pm \\
\text { standard deviation (\%) }\end{array}$ \\
\hline \multirow{6}{*}{1} & \multirow{2}{*}{ Benzylpenicillin } & 1 & \pm \pm- & $0.87 \pm 0.03$ & $87.0 \pm 3.0$ \\
\hline & & 4 & +++ & $3.65 \pm 0.23$ & $91.25 \pm 5.75$ \\
\hline & \multirow{2}{*}{ Ampicillin } & 2 & \pm \pm \pm & $1.79 \pm 0.06$ & $89.5 \pm 3.0$ \\
\hline & & 4 & +++ & $3.55 \pm 0.14$ & $88.75 \pm 3.5$ \\
\hline & \multirow{2}{*}{ Cefapirin } & 5 & + \pm \pm & $4.88 \pm 0.10$ & $97.6 \pm 2.0$ \\
\hline & & 10 & +++ & $9.02 \pm 0.27$ & $90.2 \pm 2.7$ \\
\hline \multirow{6}{*}{2} & \multirow{2}{*}{ Benzylpenicillin } & 1 & \pm \pm \pm & $0.93 \pm 0.02$ & $93.0 \pm 2.0$ \\
\hline & & 4 & +++ & $3.76 \pm 0.13$ & $94.0 \pm 3.25$ \\
\hline & \multirow{2}{*}{ Ampicillin } & 2 & \pm+ \pm & $1.77 \pm 0.05$ & $88.5 \pm 2.5$ \\
\hline & & 4 & +++ & $3.83 \pm 0.11$ & $95.75 \pm 2.75$ \\
\hline & \multirow{2}{*}{ Cefapirin } & 5 & \pm \pm \pm & $4.72 \pm 0.10$ & $94.4 \pm 2.0$ \\
\hline & & 10 & +++ & $9.23 \pm 0.30$ & $92.3 \pm 3.0$ \\
\hline
\end{tabular}

a) "-", negative result. Double red lines in T and C line were observed. " \pm ", weakly positive result. A weaker T line together with a red C line was observed. “+”, positive result. A single red C line with no T line was observed.

based on the indirect labeling receptor by an antibody, the established assay can detect the above four drugs, with cut-off values meeting their MRLs. The reason for the improved sensitivity may be that the indirect labeling receptor can prevent the active sites of receptor from being masked. In addition, with an antibody as a linker, the detection signal can be amplified.

The biosensor cannot detect vancomycin, gentamicin, erythrocin, tetracycline, and sulfadimidine (Fig. S5), which are highly contaminated antibiotics in milk samples. Thus, the assay shows high specificity to $\beta$-lactam antibiotics.

\section{Recovery analysis}

To validate the reproducibility and accuracy of the de- veloped analytical method, two types of milk samples were spiked with target analytes and analyzed using the biosensor and LC-MS/MS. Three commonly used $\beta$-lactams, benzylpenicillin, ampicillin, and cefapirin, were separately spiked into milk at concentrations comparable to their respective vLODs and cut-off values. The results listed in Table 2 indicate that the biosensor exhibited high reproducibility. Furthermore, the results obtained by the proposed biosensor method are in good agreement with those obtained by LC-MS/MS, suggesting that the receptor antibody-based biosensor could be used to determine $\beta$-lactams with good accuracy.

\section{CONCLUSION}

By combining antigen-antibody and receptor-ligand re- 
actions, a portable, sensitive, and simple biosensor was developed for the qualitative screening of $\beta$-lactam residues in milk samples. The use of anti-receptor antibody and small amounts of receptor protein gives the assay a higher sensitivity than conventional receptor-based assays and a broader spectrum recognition than antibody-based immunoassays. This lateral flow immunoassay biosensor offers an excellent on-site and high-throughput screening method, because the samples do not require any pretreatment and each test can be completed within $15 \mathrm{~min}$.

\section{Received 17 September 2020; accepted 25 November 2020;} published online 10 February 2021

1 World Health Organization. Global action plan on antimicrobial resistance. Geneva: WHO Press, 2015. https://www.eahp.eu/sites/ default/files/global_action_plan_eng.pdf

2 Qiao M, Ying GG, Singer AC, et al. Review of antibiotic resistance in China and its environment. Environ Int, 2018, 110: 160-172

3 Hu FP, Guo Y, Zhu DM, et al. Resistance trends among clinical isolates in China reported from CHINET surveillance of bacterial resistance, 2005-2014. Clin Microbiol Infec, 2016, 22: S9-S14

4 Ma L, Li B, Zhang T. New insights into antibiotic resistome in drinking water and management perspectives: A metagenomic based study of small-sized microbes. Water Res, 2019, 152: 191201

5 Holmes AH, Moore LSP, Sundsfjord A, et al. Understanding the mechanisms and drivers of antimicrobial resistance. Lancet, 2016, 387: 176-187

6 Godziszewska J, Guzek D, Głąbski K, et al. Mobile antibiotic resistance: The spread of genes determining the resistance of bacteria through food products. Postepy Hig Med Dosw, 2016, 70: 803-810

7 Piddock LJ. The crisis of no new antibiotics-What is the way forward? Lancet Infect Dis, 2012, 12: 249-253

8 Huang KHG, Cluzet V, Hamilton K, et al. The impact of reported beta-lactam allergy in hospitalized patients with hematologic malignancies requiring antibiotics. Clin Infect Dis, 2018, 67: 27-33

9 Moreno E, Laffond E, Muñoz-Bellido FJ, et al. Using beta-lactam antibiotics in patients with a history of beta-lactam allergy: Current concepts. Polish Archives Internal Med, 2017, 127: 540-549

10 Tyers M, Wright GD. Drug combinations: A strategy to extend the life of antibiotics in the 21st century. Nat Rev Microbiol, 2019, 17: 141-155

11 Wright GD. Antibiotic adjuvants: Rescuing antibiotics from resistance. Trends Microbiol, 2016, 24: 862-871

12 Tängdén T, Giske CG. Global dissemination of extensively drugresistant carbapenemase-producing enterobacteriaceae: Clinical perspectives on detection, treatment and infection control. J Intern Med, 2015, 277: 501-512

13 Legrand $\mathrm{T}$, Vodovar D, Tournier N, et al. Simultaneous determination of eight $\beta$-lactam antibiotics, amoxicillin, cefazolin, cefepime, cefotaxime, ceftazidime, cloxacillin, oxacillin, and piperacillin, in human plasma by using ultra-high-performance liquid chromatography with ultraviolet detection. Antimicrob Agents Chemother, 2016, 60: 4734-4742

14 Carlier M, Stove V, De Waele JJ, et al. Ultrafast quantification of $\beta$ lactam antibiotics in human plasma using UPLC-MS/MS. J Chromatogr B, 2015, 978-979: 89-94
15 Šestáková N, Theurillat R, Sendi $\mathrm{P}$, et al. Monitoring of cefepime in human serum and plasma by micellar electrokinetic capillary chromatography: Improvement of sample preparation and validation by liquid chromatography coupled to mass spectrometry. J Sep Sci, 2017, 40: 1805-1814

16 Li YF, Sun YM, Beier RC, et al. Immunochemical techniques for multianalyte analysis of chemical residues in food and the environment: A review. TrAC Trends Anal Chem, 2017, 88: 25-40

17 Liu J, Zhang HC, Duan CF, et al. Production of anti-amoxicillin ScFv antibody and simulation studying its molecular recognition mechanism for penicillins. J Environ Sci Health Part B, 2016, 51: 742-750

18 Tooke CL, Hinchliffe P, Bragginton EC, et al. $\beta$-Lactamases and $\beta$ lactamase inhibitors in the 21st century. J Mol Biol, 2019, 431: 3472-3500

19 Brem J, Cain R, Cahill S, et al. Structural basis of metallo- $\beta$-lactamase, serine- $\beta$-lactamase and penicillin-binding protein inhibition by cyclic boronates. Nat Commun, 2016, 7: 12406

20 Zhang J, Wang Z, Wen $\mathrm{K}$, et al. Penicillin-binding protein 3 of Streptococcus pneumoniae and its application in screening of $\beta$ lactams in milk. Anal Biochem, 2013, 442: 158-165

21 Li Y, Xu X, Liu L, et al. Rapid detection of $21 \beta$-lactams using an immunochromatographic assay based on the mutant BlaR-CTD protein from Bacillus licheniformis. Analyst, 2020, 145: 3257-3265

22 Li Y, Wang Z, Sun L, et al. Nanoparticle-based sensors for food contaminants. TrAC Trends Anal Chem, 2019, 113: 74-83

23 Duan J, Zhan J. Recent developments on nanomaterials-based optical sensors for $\mathrm{Hg}^{2+}$ detection. Sci China Mater, 2015, 58: 223240

24 Li Y, Liu L, Song S, et al. A rapid and semi-quantitative gold nanoparticles based strip sensor for polymyxin B sulfate residues. Nanomaterials, 2018, 8: 144-155

25 Ma L, Wang Z, Liu H, et al. Monoclonal antibody production and the development of a quantitative time-resolved fluoroimmunoassay for rifaximin in milk. Food Agric Immunol, 2019, 30: 1135-1147

26 Zhang S, Wu ZY, Zhou K, et al. Development of a competitive indirect ELISA for high-throughput screening of hydrocortisone in cosmetic sample. Food Agric Immunol, 2019, 30: 594-605

27 Chen Y, Liu L, Xu L, et al. Gold immunochromatographic sensor for the rapid detection of twenty-six sulfonamides in foods. Nano Res, 2017, 10: 2833-2844

28 Meng X, Ji D, Zhang W, et al. Determination of 3.5-dinitro- $N^{\prime}-(5-$ nitrofurfurylidene) salicylic acid hydrazide in fish using immunochromatographic strip tests. Food Agric Immunol, 2019, 30: 475-486

29 Hwang J, Lee S, Choo J. Application of a SERS-based lateral flow immunoassay strip for the rapid and sensitive detection of staphylococcal enterotoxin B. Nanoscale, 2016, 8: 11418-11425

30 Song S, Suryoprabowo S, Liu L, et al. Development of an immunochromatographic strip test for rapid detection of sodium nifurstyrenate in fish. Food Agric Immunol, 2019, 30: 236-247

31 Wang Z, Guo L, Liu L, et al. Colloidal gold-based immunochromatographic strip assay for the rapid detection of three natural estrogens in milk. Food Chem, 2018, 259: 122-129

32 Wang W, Liu L, Song S, et al. Gold nanoparticle-based strip sensor for multiple detection of twelve Salmonella strains with a genusspecific lipopolysaccharide antibody. Sci China Mater, 2016, 59: 665-674

33 Suryoprabowo S, Liu L, Kuang H, et al. Gold immunochromato- 
graphic assay for simultaneous detection of sibutramine and sildenafil in slimming tea and coffee. Sci China Mater, 2020, 63: 654659

34 Li Y, Liu L, Song S, et al. Development of a gold nanoparticle immunochromatographic assay for the on-site analysis of 6-benzylaminopurine residues in bean sprouts. Food Agric Immunol, 2018, 29: 14-26

35 Huang CR, Lin CH, Hsiao SC, et al. Drug interaction between valproic acid and carbapenems in patients with epileptic seizures. Kaohsiung J Med Sci, 2017, 33: 130-136

Acknowledgements This work was financially supported by the National Key R\&D Program of China (2019YFC1606603).

Author contributions Kuang $\mathrm{H}$ and $\mathrm{Xu} \mathrm{C}$ conceived and designed the experiments; Li Y performed the experiments; Sun L, Liu L and Kuang H performed the data analysis. All the authors drafted the manuscript, and read and approved the manuscript prior to submission.

Conflict of interest The authors declare that they have no conflict of interest.

Supplementary information Experimental details and supporting data are available in the online version of the paper.

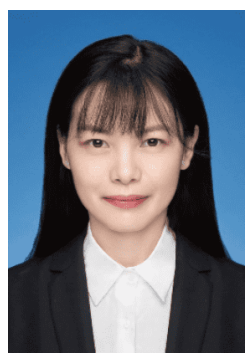

Yue $\mathbf{L i}$ is a $\mathrm{PhD}$ candidate under the supervision of Prof. Chuanlai Xu at Jiangnan University. Her research interests focus on developing rapid and sensitive methods to determine analytes using immunochromatography strip test.

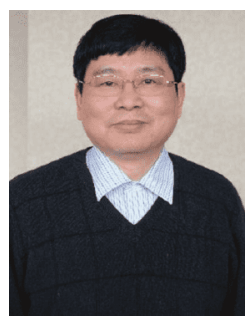

Chuanlai Xu is the Director of the International Lab of Biointerface \& Biodetection, Jiangnan University, leader of the Food Safety Innovation Team in Priority Areas Accredited by the Ministry of Science and Technology and fellow of the Royal Society of Chemistry. His research interests include: (1) fabrication of nano-devices and their applications in biotechnology; (2) preparation of antibodies against hazards (such as heavy metals, pesticides, and veterinary drug) and their applications in rapid detection.

\section{结合抗体-抗原反应和受体-配体反应建立胶体金 生物传感器用于检测 33 种 $\beta$-内酰胺类抗生素}

李月 ${ }^{1,2}$, 刘丽强 ${ }^{1,2}$, 胥传来 ${ }^{1,2^{*}}$, 匡华 ${ }^{1,2^{*}}$, 孙丽 ${ }^{3}$

摘要 本文结合受体-配体反应和抗体-抗原反应, 建立了一种新型 的侧流免疫传感器, 用于牛奶中 $\beta$-内酰胺类抗生素的残留检测. 该 传感器以地衣芽狍杆菌来源的突变型 $\beta$-内酰胺类抗生素传感受体 蛋白 (BlaR-CTD-M) 为识别元件, 以胶体金 (CG)标记的受体抗体-受 体复合物为信号传递探针. 基于样品中游离的 $\beta$-内酰胺类抗生素竞 争抑制CG/受体抗体-受体复合物与检测线处固定的 $\beta$-内酰胺类抗 生素抗原的结合, 根据检测线的颜色变化可实现 $\beta$-内酰胺类抗生素 的快速定性检测. 通过受体抗体作为连接臂, 以CG间接标记受体, 使该传感器能检测牛奶中 33 种 $\beta$-内酰胺类抗生素, 检测限符合最 大残留限量. 本文所建的传感器检测方法是一种现场快速定性篎 查 $\beta$-内酰胺类抗生素残留的有效工具. 